\title{
THE SUCCESS OF THE TEACHING METHODS OF PROPHET MUHAMMAD (PBUH) IN ENGINEERING EDUCATION
}

\author{
Zin Eddine Dadach \\ Department of Chemical and Petroleum Engineering, Abu Dhabi Men's College, \\ Higher Colleges of Technology (HCT) \\ St \# 19, Muroor Road, Al Saada Street, Al Nahyan - Abu Dhabi - Uni Emirat Arab \\ Email: zdadach@hct.ac.ae
}

\begin{abstract}
Literature has shown that effective teachers have succeeded in making students feel good about school and learning, thus increasing student achievement. Moreover, students in an actively taught class do a better job of learning (memorizing) the material they are exposed to, compared to those in a passively taught section. The main goal of this paper is to show that the teaching methods of Prophet Muhammad (PBUH) are successful tools for engineering education. First, to fully deliver his message, Prophet Muhammad (PBUH) addressed the hearts of followers to become the beloved one in order to inspire them to listen to his message. Secondly, in order to maximize the effects of his message, he used a type of speech that made his followers think during his educational methods. He utilized analogies and active learning strategies to enhance the imagination and curiosity of the listeners. As utilized by The Prophet (PBUH), the literature review highlights the use of analogies and active learning have a positive impact on both performance and the motivation of students to learn. Moreover, these teaching strategies engage students in higher thinking to be deeply involved in learning. From this perspective, the success of the utilization of the teaching methodology of our Beloved Teacher (PBUH) is demonstrated by the fact that the performance of thirty-eight $(69 \%)$ students was higher in a process control course than the average performance in the department. Additionally, the results also show that the combined methodology, including analogies and active learning, increased the intrinsic motivation of twenty-two $(40 \%)$ students.
\end{abstract}

Keywords: active learning, engineering education, Prophet Mohammad (PBUH), teaching methods

\begin{abstract}
Abstrak: Literatur telah menunjukkan bahwa guru yang efektif telah berhasil membuat siswa merasa nyaman dengan sekolah dan pembelajaran, sehingga meningkatkan prestasi siswa. Selain itu, siswa di kelas yang diajar secara aktif melakukan pekerjaan yang lebih baik dalam mempelajari (menghafal) materi yang mereka hadapi, dibandingkan dengan siswa yang diajarkan secara pasif. Tujuan utama dari tulisan ini adalah menunjukkan bahwa metode pengajaran Nabi Muhammad (SAW) adalah metode yang berhasil pada pendidikan teknik. Pertama, untuk menyampaikan dakwahnya secara utuh, Nabi Muhammad (SAW) berpesan di hati para pengikutnya untuk menjadi yang dicintai agar menginspirasi mereka untuk mendengarkan dakwahnya. Kedua, untuk memaksimalkan efek pesannya, beliau menggunakan jenis pidato yang membuat pengikutnya berpikir selama metode pendidikannya. Dia menggunakan analogi dan strategi pembelajaran aktif untuk meningkatkan imajinasi dan keingintahuan pendengar. Seperti yang digunakan oleh Nabi (SAW), berbagai pustaka menyoroti penggunaan analogi dan pembelajaran aktif yang berdampak positif pada kinerja dan motivasi siswa untuk belajar. Selain itu, strategi pengajaran ini melibatkan siswa dalam pemikiran yang lebih tinggi untuk terlibat secara mendalam dalam pembelajaran. Dari perspektif ini, keberhasilan pemanfaatan metodologi pengajaran Nabi besar Muhammad SAW ditunjukkan oleh fakta bahwa kinerja 38 (69\%) siswa lebih tinggi dalam kursus kontrol proses daripada kinerja rata-rata pada afiliasi. Selain itu, hasil juga menunjukkan bahwa metodologi gabungan, termasuk analogi dan pembelajaran aktif, meningkatkan motivasi intrinsik 22 (40\%) siswa.
\end{abstract}

Kata Kunci: metode pengajaran, Nabi Muhammad (SAW), pembelajaran aktif, pendidikan teknik,

\section{Introduction}

The relationship between knowledge and action is a key topic in psychology and, according to Joachim Funke (2017), it is not possible to act without knowledge. However, every new-born baby has the instinct to latch on and suck milk rhythmically from the breast of their mother and that instinctive action requires knowledge, so who gave them this knowledge in order to be able to live? The other example which shows that Allah SW'T is the One who teaches us everything is in the Quranic verse "And among you there is he who is brought back to the miserable age, so he knows nothing after having known" (Quran; 22: 5) (Al Hilali \& Khan ,1996). This Quranic verse can be exemplified by the state of forgetting even the names and faces of family members, which is commonly known as Alzheimer's 
disease, and usually affects people over sixty-five years of age. Therefore, by His beautiful Names "The All-Knowing One" and "The Prime Light", Allah SW'T is the absolute teacher and the absolute fuide of humanity as mentioned in the Quranic verse "And Allah taught Adam all the names" (Quran; 2: 31) (Al Hilali \& Khan,1996).

In order to emphasize the role of seeking knowledge in Islam, the first Quranic verse sent to Prophet Muhammad (PBUH) by Allah (SWT) through Angel Gabriel started with "Read!" (Quran; 96: 1-5) (Al Hilali \& Khan, 1996). The followers of the Prophet (PBUH) were devoted to the cause of education. Although teaching was based mainly on oral traditions; they began wholeheartedly to seek knowledge about Islam with great interest and enthusiasm. They were influenced by the love and the effective methods and strategies of the teachings of Prophet Muhammad (PBUH). From this perspective, his teaching methods are mainly based on analogies and active learning (Gultekin, 2012; Shaarawy; 2014). Similar to the analogies used regarding Prophet Muhammad (PBUH); many science and engineering teachers also successfully used them to build conceptual bridges for students between what is familiar (an analogy concept) and what is new (a target concept) (Fernandez-Torres, 2005; Iveson, 2006; Glynn, 2008; Foos, 2010)

According to Yelamarthi et al. (2006), some of the immediate positive outcomes in using analogies are; increased student motivation, better participation in class and laboratory exercises, better rapport between the student and instructional group, increased creative thinking of the students and active student participation in providing valuable course feedback. Moreover, because engineering students need to work with real process applications, charts, diagrams, hands-on practices, and demonstrations concurrently with theory, equations, and words, they are also encouraged to become active rather than passive learners by developing collaborative and co-operative skills, and lifelong learning skills (Fraser, 2008). To further this, Hattie (2009) and Marzano \& Pollock (2001) have independently used statistical methods to average the findings of many thousands of the most rigorous studies on active learning. Their findings show that, for the best active methods, if a student is put in the active-learning group, then on average, $\mathrm{s} / \mathrm{he}$ will do more than a grade and a half better than if $\mathrm{s} / \mathrm{he}$ had been placed in the traditional learning group. To support the efficiency of the active learning strategies, literature shows that students could retain up to $90 \%$ of what they learn through direct experience (Edgar, 1969).

\section{A. The Prophet (PBUH)'s Teaching Style and Engineering Education Methods}

While the mosque in Medina became the home of worship, it also became the central place for spreading Islamic education. To be able to fully transmit his message, Prophet Muhammad (PBUH) first addressed the hearts of followers to become the beloved ones in order to inspire them to listen to his message. Secondly, in order to maximize the effects of his message that could permanently transform the behaviour of people, he used a type of speech that made his followers think during his educational methods (Gultekin, 2012). He utilized analogies to enhance the imagination and curiosity of the listeners. For example, the Prophet (PBUH) asked his companions, "What would be the situation of someone who has a river at his door and every day, five times a day, he comes out and he takes a bath in that river? At the end of the day would he have any dirt on himself?" They responded, "There would be no dirt on him, O Rasul Allah." Then the Prophet said, "Similarly there are the five prayers cleansing the person in this way (Gultekin, 2012; Shaarawy, 2014)". He also used to compare the tangible to the intangible. For example, He said, "Charity extinguishes the sins like water extinguishes the fire" (Munajjid, 2011).

Nowadays, many science educators use analogies as a tool for more effective teaching. For example, Iveson (2006) explained why counter-current is more efficient than co-current using a simple example of two basins used to clean dishes in stages. In a chemical engineering course, Fernandez-Torres (Fernandez-Torres, 2005) used different analogies (number of male and female students in a university, a drink with orange and water) to explain mass and molecular fractions to freshmen. In a chemistry course, Foos (2010) used cartoon characters to explain electronegativity, redox reaction and electron delocalization. According to Yelamarthi et al. (2006), increased student motivation, better participation in class and laboratory exercises, better ratio between the student and instructional group, increased 
creative thinking of the students and active student participation in providing valuable course feedback, are some of the immediate positive outcomes in using analogies.

The teaching strategies of Prophet Muhammad (PBUH) were also based on living experiences (active learning) as opportunities to instruct. For example, The Prophet (PBUH) once was with some companions to prepare food, and he asked them to slaughter a sheep. One companion said he would do that, another said he would skin it, and a third said he would cook it. Then the Messenger of Allah SWT replied, "I will collect wood for the fire". They said, "No, we will do that work for you." The Prophet (PBUH) answered, "I know that you can do it for me, but Allah SWT hates to see a servant of his privileged above others." And the Prophet went and collected firewood. As the Prophet (PBUH) used analogy to explain a topic verbally, he also used illustration to make a point graphically. In this context, the Prophet drew a straight line through the sand and then drew lines to the right and lines to the left of the first line (Gultekin, 2012; Shaarawy, 2014). Then, while the people were looking attentively at the drawing, he recited the Quranic verse “And verily, this (Allah' commandments) is My Straight Path, so follow it, and follow not (other) paths for they will separate you away from His Path" (Quran; 6: 153) (Al Hilali \& Khan, 1996). On other occasions, he illustrated his point using his hand as once he said, "I and the one who takes care of the orphans are in paradise, like this (as he was speaking, he interlaced his fingers) (Gultekin, 2012). As utilized by Prophet Muhammad (PBUH), active learning methodology is nowadays fundamental for engineering education. For example, in an introduction to an engineering course at Rowan University, a discussion on fluidized beds was associated to a laboratory experiment on fluidized bed coating developed at the university (Hesketh et al., 2002). During a mechanical engineering course, a series of simple experiments on mechanics, fluid dynamics and electrical circuits were developed to enhance freshmen's abilities to apply engineering concepts, design experiments and motivate the learning of computer tools (Lyons \& Brader, 2004). According to Wankat \& Orevitz (1993), some benefits of active learning are motivation, problem identification, discovery, induction and opportunity to build and test lab experiments that are memorable.

\section{B. Applying the Teaching Methods of The Prophet (PBUH)}

In order to help students absorb the maximum amount of knowledge and skills that correspond to their innate aptitude, the two methods by which The Prophet (PBUH) taught his companions have been incorporated into my teaching strategy at the Chemical \& Petroleum Engineering Department of the Higher Colleges of Technology (UAE). A combination of the use of analogies and active learning was inspired by the fact that students in the department link an equation learned in a course as a unique theory specific to the subject and fail to realize that it is part of a more universal principle that can be applied to a wide variety of natural phenomena. Due to this, they are able to use formulae related to the theory perfectly but fail to visualize the basic concepts hidden behind the applications. This situation is further complicated because sophisticated tools and difficult software, like HYSYS, are utilized by students in order to solve chemical engineering problems. The students can easily memorize how to utilize the complex tool whilst failing to understand the fundamental principles employed by the software developers to write the corresponding subroutines. As a result, without having the ability to create a bridge between the theory and its applications, students will often have misconceptions and learning difficulties. Students could consequently be disengaged from the learning process and end up relying on mobiles in classrooms. In contrast, engineers need critical and creative thinking to solve technical problems or innovate new processes. Therefore, in order to equip engineering students with the requisite skills for their future job, developing analytical skills is far more important than just relaying information. So what teaching strategies can engage students in thinking and thus, be deeply involved in learning?

Firstly, just as the Prophet (PBUH) used to draw and teach from life experiences; an active learning strategy combined with an analogy were utilized during a process control course. The objective of the application of this combined strategy was to help students make relevant connections within course materials; transforming course material from opaque language into something they could visualize and integrate into their own knowledge network. The analogy between process control systems and "brain/body" interactions was deployed extensively in this course to help students create a link between 
what they already know about brain/body mechanisms and the sophisticated concepts of control theory. For the active learning strategy, class activities were based on Pair Problem Solving (PPS); a co-operative learning strategy. Moreover, six lab experiments were part of the active learning strategy to encourage students to understand in depth the theory of process control and learn how to apply it. Problem-based learning (PBL) is another activity used in the active learning strategy. The objective of the project was to promote the students' curiosity and drive for exploration, using all the library resources to search for the latest technologies and applications of process control for a specific application.

In order to demonstrate the effects of the use of the combination of analogies and an active learning strategy on the motivation of students, a new approach based on the following general equation was developed (Dadach, 2013):

\section{Flow $\propto($ Driving Force $) /$ Resistance}

Using equation (1), what students learn could represent the "Flow" of information from the teacher (the source of knowledge). It is also assumed that a student having a low CGPA could present a higher "Resistance" to receiving the information and, by consequence, to his motivation and performance (Dadach, 2013). Since nothing can be done about the student's CGPA "Resistance", the use of analogies and an active learning strategy can be used as the "Driving Force" in order to enhance the information "flow" in the brain of the students. It is also assumed that the "Flow" of information could be approximately represented by the Final Grade Point (FGP), which was assumed to be a direct measure of student performance. Introducing a correction factor $(\propto)$, the Dadach Motivation Factor (DMF) of students is introduced (Dadach, 2013):

$$
\mathrm{FGP}=(\mathrm{DMF}) \cdot(\alpha) \cdot(\mathrm{CGPA})
$$

Equation (2) is the first quantitative method utilized to measure the effects of an active learning strategy on student motivation. For any innate ability (CGPA) of students to learn, the teaching strategies that increase the intrinsic motivation (DMF) of students will be able to enhance the volume of flow of information (FGP) of each student by unlocking (her/his) full inborn potential. It will then result in the maximum possible amount of knowledge being obtained in the course and the highest ability to master the required skills for their future job. The success of the deployment of this teaching methodology of our Beloved Teacher (PBUH) has been displayed by the fact that the performance of thirty-eight $(69 \%)$ students was higher in the process control course than their average performance in the department. Moreover, the results show the combined methodology also increased the intrinsic motivation of twentytwo (40\%) students (Dadach, 2013).

The teaching methodology of Prophet Muhammad (PBUH) was additionally employed in an introductory course of chemical engineering designed for freshmen with a weak high school scientific background (Dadach, 2016). Also, based on a combination of analogies and active learning, it was intended to provide freshmen with a global overview of the field of chemical engineering and help them visualize the elementary principles of Transport phenomena, Thermodynamics, Energy conservation and Energy efficiency. The Learning outcomes (LO's) of the course are related to the following chapters: (1) Electricity; (2) Fluid Dynamics; (3) Heat Transfer; (4) Mass Transfer \& Solubility; (5) Thermodynamics; and (6) Energy efficiency. To make transport phenomena easier to understand, traffic situations on different roads within Abu Dhabi were selected as the analogy to visualize movements during chemical engineering processes. A second analogy was used in the course to create a bridge connecting the chemical affinity between different species and the affinity between people. The selected analogy for affinity is language. For example, in a foreign country, people who speak the same language stay together because they feel comfortable and can communicate with each other. It is then explained that, like people, two different chemical species can mix because of some affinities (like dissolves like). In the thermodynamic chapter of the course, money in different currencies was selected as the third analogy to make energy conservation easier to understand. In order to explain that natural movements are only from 
high energies to low energies, the fourth analogy used in this course is physical strength. During the class activity, a strong student and a weak student (as a reference) of each group were asked to perform armwrestling. To motivate freshmen with a weak high school scientific background to make effort and keep learning, the last analogy used in this introduction course is the well-known story of the "Tortoise and the Hare". The hare moved faster but in different directions. On the other hand, the tortoise moved slowly but steadily towards the final destination. The main point of using this analogy is to show to the freshmen with a weak scientific background that their attitude and motivation to learn are more important than their scientific background. To help students shift from the concepts of the five analogies utilized in the course to the real application engineering theories, the analogy reinforced with simple lab experiments or class activities. A faculty evaluation conducted by students indicates that most of them had fun working in groups and the different activities offered during this introductory course motivated them to learn.

\section{Conclusion}

The two main teaching methods of Prophet Mohammad (PBUH) are introduced in this paper. Indeed, in order to permanently change the behavior of his followers, He often used analogies and active learning in order to encourage thinking while listening to his divine message. Similarly, as discussed in the literature review, the use of analogies and active learning are important teaching strategies in science and engineering education in order to increase the intrinsic motivation and performance of students. A combination of these two methodologies have been successfully used in a process control course and an introduction course to chemical engineering at the Higher Colleges of Technology (UAE). For example, a faculty evaluation conducted by students indicates that most of them had fun working in groups and the different activities offered during an introductory course motivated them to learn. In the process control course, the combined teaching strategy (active earning and analogies) enhanced the intrinsic motivation of twenty-two (40\%) students.

\section{References}

Al Hilali, Muhammad Taqui-ud-Din., and Muhammad Muhsin Khan. 1996. "Interpretation of The Meanings of The Noble Quran.” Kairo: Darussalam.

Dadach, Zin Eddine. 2013. "Quantifying The Effects of An Active Learning Strategy on The Motivation of Students". International Journal of Engineering Education 29(4): 904-913.

Dadach, Zin Eddine. 2016. “An Introductory Chemical Engineering Course Based on Analogies and Research-Based Learning." International Journal of Engineering Education 32(5B): 2194-2203.

Dale, Edgar. 1969. “Audio-Visual Methods in Teaching, 3rd ed. New York: Holt, Rinehart \& Winston.

Felder, R. M., and L.K. Silverman. 1988. "Learning and Teaching Styles in Engineering Education.” Engr. Education 78 (7): 674-681.

Fernandez-Torres, M.J. 2005. "Those Little Tricks That Help Students to Understand Basics Concepts in Chemical Engineering." Chem. Eng. Ed 39 (4): 302-307.

Fraser, Duncan. 2008. "The Phumelela Project: Improving The Success of Engineering Students. Proceedings of the 36th SEFI Annual Conference, 35.

Funke, Joachim. 2017. "How Much Knowledge is Necessary for Action? In Knowledge and Action.” Germany: Springer.

Glynn, S. M. 2008. "Making Science Concepts Meaningful To Students: Teaching With Analogies,” in Four Decades of Research in Science Education: From Curriculum Development to Quality Improvement, Ed. S. Mikelskis-Seifert., U. Ringelband., and M. Brückmann. Münster, Germany: Waxmann.

Gultekin, Vahap. 2012. "The Educational Methods of Our Prophet (PBUH)". The Pen Magazine. November 9: 16. http://www.thepenmagazine.net/the-educational-methods-of-our-prophet-pbuh/.

Hattie, John. 2009. “Visible learning: A synthesis of Over 800 Meta-Analyses Relating to Achievement.” London: Routledge.

Hesketh, Robert. P., C. Stewart Slater., Stephanie Farrelli., and Michael Carney. 2002. "Fluidized Bed Polymer Coating Experiment." Chemical Engineering Education 36(2): 138-143.

Iveson, S. 2006. "Explaining Why Counter-Current is More Efficient than Co-Current." Chemical Engineering Education 36(4): 257- 263.

Lyons, Jed S., and John S. Brader. 2004. "Using The Learning Cycle to Develop Freshmen's Abilities to Design and Conduct Experiments." International Journal of Mechanical Engineering Education 32(2): 126-134.

Marzano, R., D. Pickering and J. Pollock. 2001. "Classroom Instruction that Works. Research-Based Strategies for Increasing Student Achievement, Association for Supervision and Curriculum Development." Alexandria, VA: Association of Supervision and CurriculumDevelopment.

Munajjid, S.M.S. 2011. "Islam Question and Answer. Available from: https://islamqa.info/en/146238. 
Shaarawy, Kamal. 2014. "The Teaching Methods of the Prophet Muhammad (PBUH); The Message International Magazine." https://messageinternational.org/the-teaching-methods-of-the-prophet-muhammad-pbuh/.

Wankat, P., and F.S. Oreovicz. 1993. “Teaching Engineering”. New York: McGraw-Hill.

Wu, Chun., and Jordan Foos. 2010. "Making Chemistry Fun to Learn.” Literacy Information and Computer Education Journal (LICEJ) 1(1): 3-7.

Yelamarthi, Kumar., Sridhar Ramachandran., and P. Ruby Mawasha. 2006. "The Practical Use of Analogies to Mentor The Engineer of 2020. 2006 Illinois-Indiana and North Central Joint Section Conference. 1-7. 